\title{
Language and Identities: The Exceptional Normality of Italy
}

\author{
John J. Kinder, University of Western Australia
}

\section{Unity and diversity: A tension at the heart of language ${ }^{1}$}

On 11 October 2007, the Italian Minister for the Interior, Giuliano Amato, spoke at a Rome conference on immigration at which a report, commissioned by his Ministry and entitled 'Social research on immigration: Italy,' was officially presented. When Magdi Allam, deputy editor of Italy’s largest-selling newspaper Corriere della Sera, suggested that Italy introduce a language exam for immigrants as Holland had recently done, Minister Amato responded 'I do not agree with the Dutch, who perhaps are frightened by Islam, but we are a diverse society. We must not raise the drawbridge' (ADUC 2007). ${ }^{2}$ In his initial remarks, Minister Amato had said, 'A number of centuries of history have made us tendentially white and Christian, but we must be prepared to “welcome differences”, even if there are some differences that are difficult to fit together' (Ministero dell'Interno, 2007, italics added). ${ }^{3}$

Minister Amato’s comments would warrant examination on many fronts, but their most remarkable feature is the conjunction italicized above. On one side of the but is an assertion of identity, though this identity has admittedly been imposed by 'history' and is 'tendential' at best. On the other side is a declared openness to difference, to the other,

\footnotetext{
${ }^{1}$ This article is based in part on an address given at the 28th Meeting for Friendship among the Peoples, Rimini, August 2007. I am grateful to the two anonymous Portal reviewers for helpful suggestions.

${ }^{2}$ Non sono d'accordo - ha spiegato Amato, rispondendo ad una sollecitazione del vicedirettore del Corriere della Sera, Magdi Allam—con gli olandesi, che forse sono impauriti dall'Islam, ma noi siamo una società diversa. Non bisogna alzare il ponte levatoio.

${ }^{3}$ Alcuni secoli di storia ci hanno reso tendenzialmente bianchi e cristiani, ma dobbiamo essere disposti ad 'accogliere le diversità,' anche se ci sono alcune 'diversità difficili da comporre.'
} 
to dialogue. The conjunction that links these two propositions-ma-is defined by grammarians as 'adversative,' 'expressing contrariety, opposition, or antithesis.' Thus for the Italian Interior Minister identity and openness to the other are in a relation of opposition. Identity is posited as an obstacle or limit to true openness to difference, and the welcoming of differences can only happen despite or against the identity of the welcomer. Identity is a threat to dialogue rather than its essential pre-condition. The experience of diversity is presented as a problem to be resolved, 'fitted together,' rather than as an encounter between identities, each perceiving itself and its interlocutor as other, each open to encounter as an elementary mode of knowledge.

It is no surprise, however, that the Minister's comments should have been made in response to a question on language. Language has always been a symbol and barometer of cultural life. Antonio Gramsci's judgement can apply to all modern nation states, though he was referring specifically to Italy's 'questione della lingua,' the debate on the nature of the national language that raged from the 16th to the 20th centuries: 'Every time the language question surfaces, in one way or another, it means that a series of other problems are coming to the fore: the formation and enlargement of the governing class, the need to establish more intimate and secure relationships between the governing groups and the national-popular masses, in other words to reorganize the cultural hegemony' (Gramsci 1985: 183-84). ${ }^{4}$

Issues of language policy loom large in contemporary cultural debates in Italy. The fundamental issues are perennial and unchanging but are being negotiated in a rapidly evolving social and cultural context. At the centre of these language debates is a tension that lies at the heart of language itself. Language is at once a way to imagine the world and communicate that conceptualization to an other and build shared understandings. Through being at the whim of its users, language is also a source and instrument of miscommunication. Language is both an expression of elemental human experience, which is universal and common, and also the symbol of the uniquely different concrete set of circumstances through which each of us lives that common elementary core. Language is a tool for building unity, and an expression of irreducible difference.

\footnotetext{
${ }^{4}$ Ogni volta che affiora, in un modo o nell'altro, la quistione della lingua, significa che si sta imponendo una serie di altri problemi: la formazione e l'allargamento della classe dirigente, la necessità di stabilire rapporti più intimi e sicuri tra i gruppi dirigenti e la massa popolare-nazionale, cioè di riorganizzare l'egemonia culturale.
} 
Language provokes questions of identity, otherness and dialogue because it contains the inevitable tension between those same forces within itself. Languages are constantly caught between the opposing forces of disintegration and recomposition, of differentiation and homogenization. Indeed it would seem that the centrifugal force, towards ever increasing diversity, is a 'natural' part of the relationship between language and culture, while the opposite force, of centripetal standardization and reduction of language diversity, is external to language and is the result of non-linguistic factors or interventions. This tension within language is paralleled, on the level of theoretical reflection, by the opposition between 'relativistic' views that languages are necessarily tied to, and formed by, certain specific forms of thought, behaviour and culture, and 'universalistic' views that search for the deep constants that unite all human languages (De Mauro 1996).

This paper examines Italy’s contemporary linguistic landscape and debates in the light of this understanding of the contradiction at the heart of language. I argue that by placing Italy’s linguistic history against a wider, European and global, perspective, the exceptionality often claimed for Italy's persistent diversity appears not so much an exception to a general rule, but on the contrary, a particularly clear example of universal trends. While these trends have been diverted in particular directions in other places, Italy carries on an atavistic tension between diversity and unity in thoroughly modern terms, a kind of exceptional normality.

\section{Language and languages in contemporary Italy}

Italy is a place of wondrous linguistic diversity. ${ }^{5}$ Though the national language is now universally spoken by the native-born population, it behoves us to recall how recent and rapid the Italianization of the country has been. Italian speakers at the time of national Unification in 1861 were little more than one-tenth of the population: estimates range from 2.5 per cent (De Mauro 1963) to 9.5 per cent (Castellani 1982) and twelve per cent (Serianni 1990: 18). In 1951 Italian-only speakers were still a mere eighteen per cent of the population, another eighteen per cent alternated use of Italian and dialect on a daily basis, while for the remaining sixty-four per cent of Italians the only language used with daily regularity was their local dialect.

\footnotetext{
${ }^{5}$ Summary information can be found in the language entries in the Routledge Encyclopedia of Contemporary Italian Culture, listed at Moliterno (2000: xvii).
} 
It is worth recalling, too, that in the Italian context dialects are 'in effect separate Romance languages and they can differ from each other as much as French differs from Spanish. These Italian dialects are not derived from Italian, nor are they varieties or adaptations of the national language’ (Lepschy, Lepschy \& Voghera 1996, 70). The latest language survey by ISTAT (2007) reveals that in 2006 use of dialect within the home (usually together with Italian) is still a daily reality for nearly half the population of Italy (48.5 per cent). Dialect usage correlates positively with age, male gender, bluecollar occupations, and with the North-East, South and islands, although the geographical differences are diminishing in recent years. The long predicted demise of the dialects is slow to materalize. The Corriere della Sera (2007) somewhat ambiguously reported the findings of this ISTAT survey by declaring Italy to be a 'Babele di dialetti.'

Language borders, so determinant in creating identities, interweave across and around Italy's external political borders and through the internal borders of regioni and province. The Romance language 'family' is conventionally divided into a 'Western' group including Portuguese, Spanish, Catalan, French, and so on, and an 'Eastern' group including Sardinian, Sicilian and Romanian. The conventional divide, the socalled 'La Spezia-Rimini line,' passes from east to west right across the peninsula, so that the dialects of northern Italy belong to Western Romance while those of central and southern Italy belong to Eastern Romance.

A striking feature of the contemporary scene is the presence of islands of languages other than Italian. There are nearly 3,000,000 individuals, in thirteen out of Italy’s twenty administrative regions, who speak a mother tongue other than Italian or an Italian dialect. Italy's linguistic minorities, most of which can be traced to historical immigrations or changing borders, are found mainly in border areas (Valle d'Aosta, Alto-Adige, Friuli, etc.), or in scattered enclaves. Sardinian and Friulian are now recognised as 'minor languages' rather than dialects.

Since the 1970s immigration has brought into Italy languages of all the continents, especially northern Africa, eastern Europe, the Indian sub-continent, eastern Asia and South America. The number of 'regular' immigrants in 2006 is estimated at 3,690,000, with a little over 120,000 'irregular’ migrants (Caritas/Migrantes 2007). The ISTAT 
survey cited above (2007) claims that five per cent of Italian residents regularly speak 'another language' in the home, that is, neither Italian or a dialect, nor one of the 'historical minority languages.' In other words, the new linguistic minorities are already as numerous as the old ones.

This vital diversity is often depicted as something exceptional, even extraordinary. The construction of Italian 'exceptionality’ is a recurrent topos among English-language Italianists (as discussed by Moss 1989, and in several chapters in Forgacs \& Lumley 1996) and is characteristic of certain external projections of itself by mainstream Italian culture: Italy as unique, different, refractory, unsusceptible to analyses that work for other places. I own a t-shirt featuring a memorable cartoon by Altan, that says 'The Italians are an extraordinary people, I really wish they were a normal people. ${ }^{6}$ But in matters of language, Italy is not exceptional except in being, as it were, exceptionally normal. The language diversity found within Italy is simply a particularly clear microexample of the diversity that characterizes us as a species.

\section{Language and languages in the world}

The most fundamental and most obvious characteristic of human language as it exists in the real world is, in fact, its diversity. How many languages are there in the world? Or rather, how many communities are there who recognise themselves as 'native speakers' of a particular language? These questions are as frequently asked as they are difficult to answer accurately.

Leaving aside questions of definition, for example 'language' versus 'dialect,' one reliable estimate is 6,809 (Gordon 2005). The distribution of languages world-wide is rather like the distribution of wealth, with a small number of very large languages, and many very small ones. A mere 347 (or approximately 5 per cent) of the world's languages have at least one million speakers and account for ninety-four per cent of the world's population. By contrast, the remaining ninety-five per cent of languages are spoken by only six per cent of the world's people. A mere eight million persons, 0.2 per cent of humanity, speak half the world's languages. Five hundred languages are spoken by fewer than one hundred people each, and thus will presumably disappear for ever

\footnotetext{
${ }^{6}$ L'italiano è un popolo straordinario, mi piacerebbe tanto che fosse un popolo normale.
} 
within the next two or three generations. At the same time, the number of languages that have developed a written form—a useful, perhaps necessary, condition for long-term survival—has risen to 2,400 .

Our multilingual planet is populated for the greater part by multilingual humans. The multitude of languages is not shared out on an exclusive basis: the 6809 languages are distributed across the 191 sovereign state members of the United Nations. On the other hand, many of these states use the same language: Twenty-two claim 'Arabic' as an official language and a similar number claim 'Spanish,' while a larger number claim 'French,' and an even larger number claim 'English' as a national or official language. As far as we can tell, the majority of states have been multilingual and the majority of humans bilingual, in all historical periods and in all continents.

That multilingualism is such a constant in human history makes it all the more strange that language diversity is universally seen as a problem, as subversive, even a curse; those who do not speak the language of the powerful are, on those grounds, denied rights, civilization, even humanity. For the ancient Greeks, 'barbaros’ was a non-Greekspeaker whose language amounted to nothing more than babble ('ba ba'), a discriminatory view that the Romans were quick to adopt and that survives in many modern European languages.

\section{Unity and diversity in language myths}

All cultures have a story explaining the diversity of human languages, and thus of customs and cultures: a Babel story (Steiner 1975). Most of these stories attribute language diversity either to a terrible mistake-someone opened something and they all got out - or to a punishment of the gods. In the Judaeo-Christian tradition at the heart of European reflection on language diversity there are, in fact, two stories. In the first, the Babel story of the Old Testament, multilingualism is defined as a divine punishment:

\footnotetext{
And the whole earth was of one language, and of one speech. And it came to pass, as they journeyed from the east, that they found a plain in the land of Shinar; and they dwelt there. And they said one to another, Go to, let us make brick, and burn them thoroughly. And they had brick for stone, and slime had they for mortar. And they said, Go to, let us build us a city and a tower, whose top may reach unto heaven; and let us make us a name, lest we be scattered abroad upon the face of the whole earth. And the Lord came down to see the city and the tower, which the children of men builded. And the Lord said, Behold, the people is one, and they have all one language; and this they begin to do: and now nothing will be restrained from them, which they have imagined to do. Go to, let us go down, and there confound their
} 
language, that they may not understand one another's speech. So the Lord scattered them abroad from thence upon the face of all the earth: and they left off to build the city. Therefore is the name of it called Babel; because the Lord did there confound the language of all the earth: and from thence did the Lord scatter them abroad upon the face of all the earth. (Genesis 11:1-9)

At Babel humans denied their true nature as their first ancestors had done before them. The first chapter of Genesis says: 'God created human beings in his own image [...], male and female he created them. God blessed them and said to them, "Be fruitful and increase, fill the earth and subdue it”' (Genesis 1: 27-28). Their vocation is to multiply and fill the earth so as to manifest the presence of the Creator and make the world like a Garden of Eden. One of the Creator's gifts was the one common language, with which humans could speak to each other and to God.

In the Babel story humans stop taking this destiny seriously; they lose interest in the earth and seek to conquer the heavens (Lustiger 2001). The 'image' wanted to become its own model, or God's image without God. But the human who turns themself into their own idol forgets their true origin and destiny, and risks becoming the victim of their own destructive selfishness. Dante, in De Vulgari Eloquentia (I, ix), explains events at Babel as a forgetting (prioris oblivio); the tower builders forget the original language given by God and are condemned to a plurality of mutually incomprehensible tongues, in a confusion of languages, the confusio linguarum.

And the confusion did not end there. Heller-Roazen (2005: 219-31) argues that, since it was from confusion that all languages departed and multiplied in time and in space, ‘confusion' would remain inseparable from the idioms to which it gave rise. It would constitute 'the invariable core of the variable being we call a tongue' (225).

This confusion of the Old Testament story, however, is redeemed in the New Testament account of Pentecost:

And when the day of Pentecost was fully come, they were all with one accord in one place. And suddenly there came a sound from heaven as of a rushing mighty wind, and it filled all the house where they were sitting. And there appeared unto them cloven tongues like as of fire, and it sat upon each of them. And they were all filled with the Holy Ghost, and began to speak with other tongues, as the Spirit gave them utterance. And there were dwelling at Jerusalem Jews, devout men, out of every nation under heaven. Now when this was noised abroad, the multitude came together, and were confounded, because that every man heard them speak in his own language. And they were all amazed and marvelled, saying one to another, Behold, are not all these which speak Galilaeans? And how hear we every man in our own tongue, 
wherein we were born? Parthians, and Medes, and Elamites, and the dwellers in Mesopotamia, and in Judaea, and Cappadocia, in Pontus, and Asia, Phrygia, and Pamphylia, in Egypt, and in the parts of Libya about Cyrene, and strangers of Rome, Jews and proselytes, Cretes and Arabians, we do hear them speak in our tongues the wonderful works of God. (Acts 2:1-11)

Whatever actually happened in the historical record, the meaning of this event is clear in relation to the story of Babel. The divine intervention at Pentecost does not reverse the linguistic diffusion created with the building of the Tower of Babel. The early Christians do not remember the original Adamitic language; nor do they emerge all speaking the same language. The spirit does not close the 'breach' begun at Babel but, as Benedict XVI (2005) put it, overcomes the breach and opens borders. The newfound ability of the disciples to speak, or at least to be understood in a diverse array of languages, suggests that the word of God is multilingual, not monolingual.

\section{Language myths in Italy's linguistic history}

For De Mauro (2004: 58) the 'spirit of Pentecost' played an important role in the development of writing, and as such was crucial for language survival. Evangelization and the dissemination of sacred texts both presupposed a close attention to individual languages, the development of writing systems where these did not exist (the Cyrillic alphabet elaborated by St. Cyril in the ninth century is merely the most illustrious example), and the translations of texts into various languages.

Babel returned to the surface of European consciousness in the decades following the language reform of Charlemagne (Wright 1982). Through his radical language policy intervention and re-definition of 'Latin,' Charlemagne set up a new diglossia in southwest Europe. His definition of Latin, especially its pronunciation and grammar, produced a form of language that was incomprehensible to all but the tiny literate elite, while the forms of language that were in daily (spoken) use-and had been considered to be 'Latin' before the reform-were now in effect given a new definition. New spelling systems were extemporized on the basis of previous experimentation, and texts written in them appeared at various points near borders between the 'Romance' cultural area and other cultures: Strasbourg, on the border with the Germanic world; Capua, a city in the part of southern Italy that had maintained its Longobard character during and after the Carolingian period and is situated not far from the Greek areas of extremesouthern Italy; and Rioja, near the border with the Muslim territories in Spain. These 
were the new vernacular languages of the Latin world, the first records of what would become French, Italian and Spanish.

The Biblical symbol of linguistic confusion appeared in artistic representation at this time to signify the new confusion in which speakers of (neo-)Latin vernaculars now found themselves, beneath the roof of official, Carolingian 'Latin.' The first public Babel appeared on the altar of the Cathedral of Salerno around 1050, and there was a 'flood of Towers' (Eco 1995, 18) in the next few centuries. This period also saw a wave of intense theoretical speculation on the origin and nature of language, beginning with the speculative grammars of scholastic philosophy. Eco describes this moment as the birth of Europe as a self-conscious cultural reality. Europe was born as a new confusio linguarum out of its vulgar tongues. Only afterwards was it a mosaic of nations.

These myths of linguistic origin, and their parallel versions in all the cultures of the world, seem to be an attempt to account for some obvious facts about language diversity. That diversity is a constant of human experience and history, but it eludes explanation in terms of the rational use of resources. The cultural ecology of the human race would have been much more efficient, on the face of it, if the cultures of the planet had used an ever smaller number of languages instead of producing more and more of them. That is, the tension between pluralism and operative efficiency might have been resolved on a global scale more along the lines of the United Nations with its 192 member states and five official languages, instead of the European Union model with its twenty-seven member states and twenty-three official languages.

For all other (non-linguistic) forms of cultural expression, a Darwinian explanation may satisfy. They are all in some way a response to the environment in terms of adaptive variation and selective survival. But this will not do for language. It is not the case that surviving languages have more desirable characteristics than dead ones. There appears to be no correlation between linguistic wealth and the other resources of a community. The Aboriginal languages of Australia have a morphosyntax as complex as Classical Latin and Ancient Greek. No language is demonstrably adaptive in this sense.

One obvious, if partial, response to this issue is that language is much, much more than just communication. Language is the tool of thought and expression of identity, central 
in any construction and representation of humanness in both individual and collective senses. It is a truism that languages are the banners and ensigns of human groups. Furthermore, languages guard our memories and preserve our past knowledge, transmitting it to later and future generations. Any human language binds together a human community by giving it a network of communication; but it also dramatizes it, providing the means to tell, and to remember, its stories. Languages make possible both the living of a common history, and also the telling of it (Ostler 2005).

However, the telling of a 'national' story is an evolving process of selection and rejection, inclusion and exclusion. Just as language allows the story to be imagined and told, the very acts of imagining and telling can only happen in chosen varieties of language. The construction and expression of unity is also and always a declaration of difference and a judgement.

\section{Myth in the Italian historiography of language}

The narratives of language history and literary history are constructed to explain deeply shared cultural myths and to justify the formation of modern nation-states. The origins of the Italian language are traditionally traced back to AD 960, the date of the Placito di Capua, the earliest document in which 'Latin' (of the officially sanctioned sort) and the local vernacular appear side by side (Migliorini \& Gwynfor Griffith 1984). Tiraboschi’s Storia della Letteratura Italiana of 1781, the earliest work bearing that title, took its starting point from the ancient Etruscans, but after De Sanctis' Storia of 1871, histories of Italian literature, in the usual sense of literature written in Italian, begin with the thirteenth century. Note that the word italiano was not used to refer to language (lingua or linguaggio) until the early 1400s, by Leonardo, Machiavelli, Bembo and others, as exemplified by the entry on 'Italiano' in the Grande Dizionario della Lingua Italiana (1961). And in both linguistic and literary histories the term 'Italian' is now used for all periods: there is no universally accepted 'Old Italian,' to correspond to 'Old French,' 'Old Spanish’ or 'Old High German,' for example, but rather a narrative of unbroken continuity.

Language planning and policy intervention in Italy starts undisputedly with Dante, who laid the foundations, in both theory (De Vulgari Eloquentia) and practice (Divine Comedy) for an ‘Italian’ vernacular standard (Lo Bianco 2005). Dante imagined a 
nation and theorized a language with which to build it. Between the two extremes of supra-national Latin and sub-national vernaculars, he describes an intermediate, national, linguistic form. But the different layers did not exclude or cancel each other. Dante seems to have imagined multiple identities, each expressed via characteristic linguistic varieties. Sapegno (1986) cautions against speaking of a 'politically divided Italy' in Dante's time since it risks the ahistorical projection of modern categories onto a different reality. Italians in the Middle Age, she says, did not feel politically divided but simply members of one State among many, each having its own history and cultural identity. Certainly members of the Italian States felt more in common with each other than with 'barbarians,' but Sapegno suggests paradoxically that what united Italians then was their common interest in defending their own single autonomies from the arrogance of other Italians or of foreigners.

The theoretician of the official language of the new Italian State, Alessandro Manzoni, saw, like Dante, no contradiction between the official tongue and the local speech forms. Manzoni did not live to see the anti-dialectal distortion of his views by his fervent followers, and it was left to Ascoli (1873, xxviii) to point out what science and experience demonstrated, that 'our bilingual children have a privileged position in the order of intelligence. ${ }^{7}$

These are the terms of language debates in Italy up to the present. The arguments are now being recast in the light of two events: the formation of united Europe with the consequent debates on borders and identities, and the diasporic movement of people from and into Italy. These developments are presenting a challenge to reread these earlier, linear accounts. In the context of radical debates on external and internal borders of European nations, the post-Enlightenment orthodoxy of 'one nation - one language' has been not so much discredited as replicated at more and more local levels, 'one region - one language,' or even 'one town - one language’ (Dal Negro 2005). This new identification of language and local identity contains within it the potential for language to be used as a means of division and exclusion. One of the more acute tensions in contemporary debates on indigenous language rights in Italy turns on the inclusions and exclusions operated by the categories used.

\footnotetext{
${ }^{7}$ Che è anzi una condizione privilegiata, nell'ordine dell'intelligenza, questa dei figliuoli bilingui.
} 
A particularly interesting example of this is the definition of 'language minorities' in post-war Italy. Article 6 of the 1948 Constitution proclaimed that 'The Republic protects the language minorities with appropriate measures, ${ }^{, 8}$ but the terms of this article were only defined in a law of 1999-law 482/99 — 'Norms for the protection of the historical language minorities. ${ }^{99}$ The title already indicates a distinction between the traditional minorities and the newer communities formed in recent decades, and, in fact, the opening paragraph of the law provides a specific list: 'In compliance with article 6 of the Constitution and in harmony with the general principles established by European and international bodies, the Republic protects the language and culture of the Albanian, Catalan, Germanic, Greek, Slovenian and Croatian populations and of the populations which speak French, Franco-Provençal, Friulian, Ladin, Occitan and Sardinian. ${ }^{, 10}$

This law was a significant step forward but opens two questions. First, it treats all minority languages in a single category, despite their very different linguistic, cultural and political histories, and operates from an 'oversimplified and flattened image of what is actually a complex and multifaceted linguistic landscape’ (Dal Negro 2005: 116). Second, the law's definition of language minorities excludes both dialects as such - the word dialetto does not occur once in the text of the law-and the newer minorities that are the result of post-1970s immigration.

Emigration offers challenges to dominant constructions of identity and language in various ways. Carsaniga (1985) had already hinted at the way Italian emigration to Australia illuminated Italy’s 'multicultural' past. Raffaele Simone uses the history of Italian language and dialects abroad as a mirror to shed light on hidden aspects of the linguistic past of Italy. In his introduction to a volume by Hermann Haller on the Italian language in the USA, he observes: 'This book also speaks of us' (Simone 1993: x). The third volume of Serianni and Trifone’s Storia della Lingua Italiana is entitled Le altre lingue (1994), with chapters on the dialects, and also a chapter on ' $L$ 'italiano fuori d'Italia' (Italian outside Italy) and one on 'Aspetti sociolinguistici delle eteroglossie in Italia’ (Socio-linguistic aspects of heteroglossic communities in Italy).

\footnotetext{
${ }^{8}$ La Repubblica tutela con apposite norme le minoranze linguistiche.

${ }^{9}$ Norme in materia di tutela delle minoranze linguistiche storiche.

${ }^{10}$ In attuazione dell'articolo 6 della Costituzione e in armonia con i princípi generali stabiliti dagli organismi europei e internazionali, la Repubblica tutela la lingua e la cultura delle popolazioni albanesi, catalane, germaniche, greche, slovene e croate e di quelle parlanti il francese, il franco-provenzale, il friulano, il ladino, l'occitano e il sardo.
} 
Anthropologists show how Italian identities in Italy have been contested and reworked through post-Unification emigration, post-WWII internal migrations, and the immigration of the past three decades (Maher 1996). And in Italian communities abroad the second generation claim identities in ways not foreseen, and often not accepted, by their parents or the official culture of the country of origin (Baldassar \& Skrbis 1998).

In cultural studies, postcolonial readings of migrant writing turn a spotlight on 'hybridities' and multiple identities within 'Italian culture.' The several contributions to Burns and Polezzi (2003) open up questions of identity negotiation among emigrants, returned migrants and immigrants. In considering the growing number of writings by immigrants in Italy (Gnisci 2006), it is significant that Parati (2005: 54-55) has abandoned her earlier coinage of the term 'Italophone literature' because of the way it 'places the emphasis on language and on the difference between native speakers and non-native speakers, who acquire a new language through the process of migration.' But such debates can be set against an Italian canon that is already itself internally diverse. Since the codification of what we know as 'Italian' in the late Renaissance, the presence of writing in dialect has made Italian literature 'essentially the only great national literature whose dialect production forms a visceral, indissoluble whole with the rest of the heritage' (Contini 1970: 611). ${ }^{11}$ Haller speaks of Italy’s 'pervasive dual literary canon, in Tuscan and in a myriad of dialects’ (1999: 3).

\section{An exceptional normality?}

Language also unites and divides through the handing down from one generation to the next. Languages are learned by the young from the old: the very act of acquiring the mother tongue is a process of transmission of knowledge, culture, and wisdom. Italian educationalist Luigi Giussani (1997) stresses the central role of tradition in any educational process. Tradition is the working hypothesis given us by nature to confront reality:

Each one of us is born into a certain tradition. Nature casts us into the dynamic of existence, arming us with this complex instrument with which we can confront our surroundings. Every man and woman faces their external reality endowed by nature with elements that one finds in oneself as given, already offered. Tradition is that complex endowment with which nature arms us. We do not possess tradition in order to become fossilized within it, but to develop it, even to the point of profoundly changing it. But in order to transform it, we must first of all

\footnotetext{
${ }^{11}$ L'italiana è sostanzialmente l'unica grande letteratura nazionale la cui produzione dialettale faccia visceralmente, inscindibilmente corpo col restante patrimonio.
} 
act 'with' what has been given to us; we must use it. And it is through the values and richness which I have received that I can become, in my own turn, creative, capable not only of developing what I find in my hands, but also changing radically both its meaning, its structure, and perspective. (Giussani 1997: 37-38)

The handing down of language and the handing down of tradition are, in many respects, synonymous. The passage from one generation to the next is, at the same time, an act of continuity and rupture, of stability and of change.

We long for unity, for the recomposition of the fragmented post-Babel world we now speak and think in; and we long to live our diversity as mutual complementarity, as completion. We long to remember the language we have forgotten. We invent languages like Esperanto (the root is the Latin verb 'to hope': SPERARE), but this disembodied set of language rules attempts to simply cancel or ignore difference, and will always remain, as its name proclaims, a pious hope, a soul without a body.

In language, then, the desire to communicate-literally, to 'make common'—coexists, inextricably, with the desire to be different, the desire to be one with the desire to be other. Of course communication between humans takes many forms, and language is not the only means of communication. But communication of a uniquely human kind happens through language, which in its concrete manifestation always, inevitably, is a declaration of diversity.

Current language debates in Italy are reworking these essential tensions, with each contribution giving greater weight to this or that aspect of language according to the identity or identities being privileged. If Italy is exceptional in its linguistic landscape, this is simply because it embodies most clearly the tensions and differences that lie at the heart of language and all language communities. The enduring linguistic and cultural plurality within the area known as 'Italy' has provided a context where language debates have been played out against a backdrop of the essential normality of the tension between diversity and unity.

Contributions to Italian language debates from the medieval period to the twentieth century have taken a position within this essential tension. However, newer views, like those of Minister Giuliano Amato, attempt to dissolve the tension by airbrushing out the identity of one of the interlocutors in encounters defined as 'intercultural.' 
Contemporary Italy is enjoined to 'welcome differences,' but at the same time to define its own centuries-old identity as merely 'tendential.' This is a new and strange approach to dialogue that would require ideological interpretations, but that is beyond the scope of this paper. The multiple cultural and linguistic identities theorized by Dante and many others down to the present continue to form and reform, against the best efforts of power elites. Recent debates on the linguistic dimension of identities in Italy show, again, how the heart of the matter is a tension that lies at the core of language itself.

\section{Reference List}

ADUC. 2007, 'Amato contro esame lingua italiana per immigrati.' Online. Available: http://www.aduc.it/dyn/immigrazione/noti.php?id=196706 [Accessed 19 November 2007].

Ascoli, G.I. 1873, 'Proemio,' Archivio Glottologico Italiano, vol. 1, v-xli. [Also in Scritti sulla Questione della Lingua, ed. C. Grassi, Einaudi, Torino.]

Baldassar, L. \& Skrbis, Z. 1998, 'The Second Generation and the Transmission of Culture,' in Refashioning Sociology: Responses to a New World Order, eds. M. Alexander et al, Queensland University of Technology, Brisbane, 454-459.

Battaglia, S. (ed.) 1961-2002, Grande Dizionario della Lingua Italiana. UTET, Torino.

Benedict XVI, 2005, 'Homily, Pentecost Sunday,' 15 May 2005. Online. Available: http://www.vatican.va/holy_father/benedict_xvi/homilies/2005/documents/hf_benxvi_hom_20050515_priestly-ordination_en.html [Accessed 24 July 2007].

Burns, J. \& Polezzi, L. (eds), 2003, Borderlines: Migrazioni e identità nel Novecento, Cosmo Iannone, Isernia.

Carsaniga, G. 1985, Multiculturalism and Italian Studies, La Trobe University, Melbourne.

Caritas/Migrantes. 2007. Immigrazione: Dossier Statistico 2007. Online. Available: http://www.dossierimmigrazione.it [Accessed 7 December 2007].

Castellani, A. 1982, ‘Quanti erano gl’italofoni nel 1861?' Studi di Linguistica Italiana, vol. 8, 3-26.

Contini, G. 1970, Varianti e altra linguistica, Einaudi, Torino.

Corriere della Sera. 2007, 'L'italiano? No grazie, io parlo dialetto,' 21 April 2007. Online. Available: http://www.corriere.it/Primo_Piano/Cronache/2007/04_Aprile/20/dialetti_lingua_straniera_italiani. html [Accessed 23 April 2007].

Dal Negro, S. 2005, 'Minority Languages between Nationalism and New Localism: The Case of Italy,' International Journal of the Sociology of Language, vol. 174, 113-24.

De Mauro, T. 1963, Storia linguistica dell'Italia unita, Laterza, Bari.

De Mauro, T. 1996, 'Linguistic Variety and Linguistic Minorities,' in Italian Cultural Studies: An Introduction, eds. D. Forgacs and R. Lumley, Oxford University Press, Oxford, 88-101.

De Mauro, T. 2004, 'Cari italiani, come state parlando?' Lingua italiana d'oggi, vol. 1, 55-70.

Eco, U. 1995, The Search for the Perfect Language, trans. J. Fentress, Blackwell, Oxford.

Forgacs, D. \& Lumley, R. (eds) 1996, Italian Cultural Studies: an Introduction, Oxford University Press, Oxford.

Giussani, L. 1997, The Religious Sense, trans. J. Zucchi, McGill-Queen’s University Press, Montreal.

Gnisci, A. (ed.) 2006, Nuovo Planetario Italiano, Città Aperta, Troina.

Gordon, R.G. Jr. (ed.) 2005, Ethnologue: Languages of the World, 15th edition, SIL International, Dallas, Texas. Also available online: http://www.ethnologue.com [Accessed 19 November 2007].

Gramsci, A. 1985, Selections from Cultural Writings, eds. D Forgacs and G. Nowell-Smith, trans. William Boelhower, Lawrence \& Wishart, London.

Haller, H.W. 1999, The Other Italy: The Literary Canon in dialect, University of Toronto Press, Toronto. Heller-Roazen, D. 2005, Echolalias: On the Forgetting of Language, Zone Books, New York.

Istat. 2007, La lingua italiana, i dialetti e le lingue straniere. Online. Available: http://www.istat.it/salastampa/comunicati/non_calendario/20070420_00/ [Accessed 23 April 2007].

Lepschy, A.L., Lepschy, G. \& Voghera, M. 1996, 'Linguistic Variety in Italy,’ in Italian Regionalism, ed. 
C. Levy, Berg, Oxford, 69-80.

Lo Bianco, J. 2005, 'Globalisation and National Communities of Communication,' Language Problems and Language Planning, vol. 29, no. 2, 109-33.

Lustiger, J.M. 2001, 'Caritas and the City,' Helder Camara Lecture delivered at Notre Dame University, Fremantle, Western Australia, August.

Maher, V. 1996, 'Immigration and Social Identities,' in Italian Cultural Studies: An Introduction, eds. D. Forgacs and R. Lumley, Oxford University Press, Oxford, 160-177.

Migliorini, B. \& Gwynfor Griffith, T. 1984, The Italian Language, Faber \& Faber, London.

Ministero dell'Interno. 2007, 'Il ministro Amato ha presentato la ricerca Makno sull'immigrazione in Italia.’ Online. Available:

http://www.interno.it/mininterno/export/sites/default/it/sezioni/sala_stampa/notizie/ ministro/089 8_2007_10_09_presentazione_guide_in_italia_in_regola.html_2019699775.html [Accessed 19 November 2007].

Moliterno, G. (ed.) 2000, Encyclopedia of Contemporary Italian Culture, London, Routledge.

Moss, D. 1989, 'Italy Viewed: Opportunities for an Australian Perspective,' in Understanding Italy, eds C. Bettoni \& J. Lo Bianco, Frederick May Foundation for Italian Studies, Sydney, 43-56.

Ostler, N. 2005, Empires of the Word: A Linguistic History of the World, Harper Collins, New York.

Parati, G. 2005, Migration Italy: The Art of Talking Back in a Destination Culture, University of Toronto Press, Toronto.

Sapegno, M.S. 1986. 'Italia, Italiani,'’ in Letteratura italiana. Vol 5: Le Questioni, ed. A. Asor Rosa, Einaudi, Torino, 169-221.

Serianni, L. 1990, Il secondo Ottocento, Il Mulino, Bologna.

Serianni, L. \& Trifone, P. 1994, Storia della lingua italiana. III: Le altre lingue, Einaudi, Torino.

Simone, R. 1993, 'Premessa: l'italiano d'oltremare,' in H.W. Haller, Una lingua perduta e ritrovata: l'italiano degli italo-americani, La Nuova Italia, Firenze, ix-xii.

Steiner, G. 1975, After Babel: Aspects of Language and Translation, Oxford University Press, London.

Wright, R. 1982. Late Latin and Early Romance, Francis Cairns, Liverpool. 